\title{
Impact of Climate Change on Livelihood in Pothwar Region
}

\author{
Rahmatullah $^{1} \quad$ Ikhlaq Ahmed $^{2} \quad$ Syed Ahmed Shah $^{3} \quad$ Mansoor Rasheed $^{2}$ \\ Nida $\mathrm{Ali}^{4} \quad$ Ashar Sultan Kayani ${ }^{5}$ \\ 1.Department of Agricultural Extension Education, Balochistan Agriculture College Quetta \\ 2.Department of Agricultural Economics, Balochistan Agriculture College Quetta \\ 3.Directorate of Agriculture Research, District Panjgoor, Balochistan \\ 4.Department of Zoology Sardar Bahadur Khan Women's University Quetta \\ 5.Department of agriculture and resource economics faculty of Social Sciences University of agriculture \\ Faisalabad
}

\begin{abstract}
The present study employs the livelihood strategy conceptual framework to analyze data collected on 150 rural households from the three Integrated Research Sites of BVDP. Households were grouped into four welfare quartiles to identify different livelihood strategies using Principle Component Analysis based on the household assets. Three main livelihood strategies were identified through analyzing the resource availability and income in different welfare quartiles of the sample households. The livelihood strategies identified include: a) Mixed crop livestock farming with more dependence on crop production; b) Agriculture and off farm employment with half of the income from crops and livestock and half from off farm employments; c) The highest welfare quartile were those relatively more dependent on off-farm employment, less on crops and had the least income from livestock
\end{abstract}

Keywords: Climate Change, Livelihood, Potohar, Barani

DOI: $10.7176 / \mathrm{JEES} / 9-1-02$

\section{INTRODUCTION}

Barani areas make a significant contribution to agriculture and livestock production of Pakistan. Out of the total cropped area of 20 million hectares about 5 million hectares do not have any irrigation facility and completely depend on rains. In Punjab, barani areas contribute about 20 percent of cropped area. While in the Pothowar region, cropped area is over 90 percent. Rain fed areas are characterized as agricultural lands, which do not have access to any type of irrigation system. Due to the low and unreliable rainfall of the region, yields of main crops are low and farm income mostly remains insufficient to maintain the family. In Pakistan, although per capita income has increased over the years, yet the percentage of rural as well as urban population below poverty line is more than 25 percent. The absolute number of poor in the rural areas is relatively higher than urban areas. The bulk of rural population constitutes agricultural laborers, marginal and small farmers and rural artisans. About half of their income is derived from agriculture and rest from non-farm sources. Unequal distribution of land is one underlying factor responsible for rural poverty. Since, prospects for increasing cultivated area are limited due to irrigation water constraints, the strategy for poverty alleviation calls for significant increases in crop and livestock productivity through substantial enhancement of output per unit of land, animal and labor. As defined by Chambers and Conway, (1992) "livelihood is a means of living, and the capabilities, assets and activities required for it". Livelihood comprises of capabilities, assets (including both material and social resources) and activities required for a means of living. A livelihood is sustainable when it can cope with and recover from stresses and shocks and maintain or enhance its capabilities and assets both now and in the future, while not undermining the natural resource base (Carney, 1998). Livelihood strategies are the sum of all the different activities that people are doing in the context of their livelihood (Chambers and Conway, 1992). To keep the wider picture of livelihood in mind livelihood framework is presented in Figure 1. Livelihoods are shaped by a multitude of different forces and factors that are themselves constantly shifting. People-centered analysis is most likely to begin with simultaneous investigation of people's assets, their objectives (the livelihood outcomes which they are seeking) and the livelihood strategies, which they adopt to achieve these objectives (DFID 2001). 


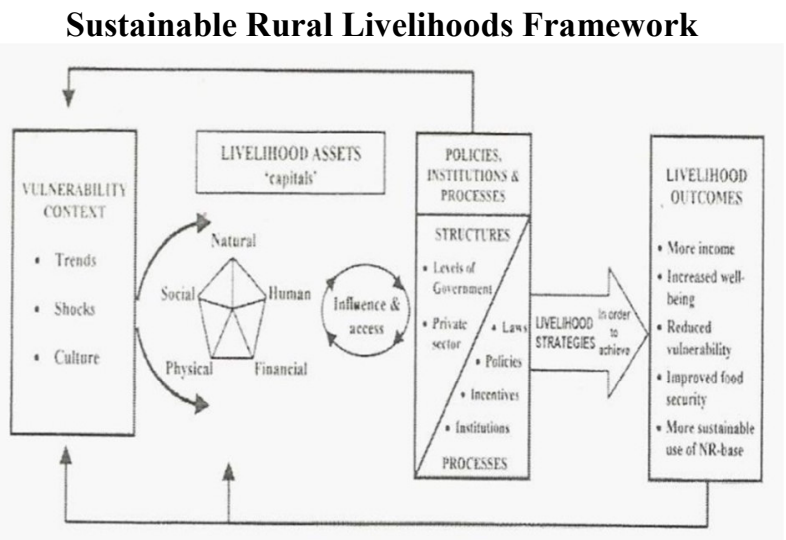

Figure 1 Diagram of Livelihood System: Source Ashley and Carney (1999)

Relationships between assets and their accessibility are very important for livelihood strategies of the people as described in DFID guidance sheets. Poverty analyses have shown that people's ability to escape from poverty is critically dependent upon their access to assets. Different assets are required to achieve different livelihood outcomes. For example, some people may consider a minimum level of social capital to be essential if they are to achieve a sense of well-being. Or in a remote rural area, people may feel they require a certain level of access to natural capital to provide security (DFID 2001). Those with more assets tend to have a greater range of options and an ability to switch between multiple strategies to secure their livelihoods. Rural livelihood strategies are shaped by several factors. In the rainfed areas climate is important for both production and consumption decisions. Other factors affecting rural household decisions are: access and control of human, natural, productive, cultural and social capital (Bebbington 1999; de Hann 2000; Valdivia, 2001), markets, institutions, and the political environment (Ellis, 1993; de Haan 2000; Ferguson 1992; Reardon et al 1992).

The purpose of understanding livelihood strategies of the rainfed farming community is to shed light on how and when individuals, households, and groups negotiate among themselves, with their communities, markets and society to improve their wellbeing or reduce food insecurity by appropriating the benefits from their assets, activities, and investments.

Objectives

- To classify the farm households in different welfare groups;

- To identify livelihood strategies of households on the basis of their asset at the farm levels;

- To perform income analysis within these groups and determine the relative poverty; and

- To suggest policy options for poverty alleviation through sustainable livelihood strategies

\section{MATERIALS AND METHODS}

\section{Universe of Study}

The population of the study area comprises of six tehsils; Attock, Jand, Talagang, Gujar Khan and PD Khan, of Pothowar tract and within these for research activities only three IRSs. Hafizabad, Jarmot Kalan and Kaslian in there tehsils, Jand, Gujar Khan and Pindadan Khan, representing the whole rainfed farming system were selected after a comprehensive site selection criteria.

\section{Data Collection}

To identify different livelihood typologies the data was collected for baseline survey following list frame. Cochran, (1963) formulae for random sampling of the known population was used. The data collected through formal surveys contain different information on natural, human, physical, financial capitals, income, and resources of the household as the unit of analysis. Survey was conducted of 150 families of the three sites.

\section{Data Analysis}

Data was analyzed using Principle Component Analysis (PCA). The first step was to select certain variables representing different livelihood capitals (natural, human, financial, physical and social) to create wealth index. The wealth index was calculated through factor analysis. Factor analysis is a statistical tool similar to principal component analysis (PCA). The primary purpose of factor analysis is to describe the relationships among many variables in terms of a few underlying but unobservable factors. Factor analysis is also similar to principalcomponents analysis in that both are attempted to approximate the covariance matrix. Factor analysis, however, is more elaborate. Seven factors were finally created and saved using factor analysis through PCA using variables like tractor ownership, irrigation source, land ownership, irrigated area, livestock and some variables representing human resources of the family.

Wealth index was calculated from these factors and the households were classified into four welfare 
quartiles after arranging in ascending order. Data was analyzed by these quartiles and different resources, income and poverty levels within these quartiles were quantified. For the simple case of comparing variation in continuous variables across single factors, one-way ANOVA was used to determine whether differences existed among the means. T-test significance and Chi-Square test significance values were recorded for quantitative and qualitative analysis. Our data lacked information on social capital therefore data mainly on other four livelihood capitals were used for factor analysis and identification of livelihood strategies of the households with different assets endowment. Finally three main livelihood strategies were identified. For data analysis SPSS-16 package was used.

\section{RESULTS AND DISCUSSION}

\section{Distribution of Households by Welfare Groups}

All the sample population was classified into four different welfare groups according to the welfare index developed through factor analysis. Although the overall distribution of households into four welfare groups was almost equal $(25 \%)$ and there was no significant difference $(\mathrm{Chi}$-sq sig. $=0.08)$ yet the households at different locations vary in different welfare groups. Relatively less households $(9 \%)$ were found in upper quartile at Hafizabad as compared to other two sites. The distribution of households according to welfare groups is given in Table 1.

\section{Human Resource Endowment by Welfare Group}

Household head remains the main driving force behind any livelihood strategy of the household. Characteristics of the household head were asked in particular to understand the farm manager's decision-making power to adopt a particular livelihood strategy. Education, experience and age of the head have strong influence on the decision regarding the crops and livestock management and farm investments.

The household heads with more off farm job experience were present in the upper welfare groups. Significant difference was found in the age, education, previous off farm job experience while except the previous off farm job experience and farming experience. All of the household heads were of old age about 50 years of age with primary to middle education level and 20 years of farming experience. The illiteracy decreases as we move to the upper welfare group where as the education level increases particularly 5-10 years of schooling towards the upper quartile (Table 2).

\section{Type of Off-Farm Work of Household Heads by Welfare Groups}

Off-farm employment particularly of the household head in plays a vital role in the livelihood of the rain fed rural community and the type of employment reflects the sustainability of the livelihood of any household. In the lowest quartile groups $44 \%$ of the household heads were belonging to labor class same proportion was engaged in business (Table 3). On the other hand half of the population in the highest welfare quartile belonged to business class followed by labor (30\%) and government servants. The type of previous off farm employment was also explored and it was found that highest percentage of households were in government service. This proportion is much higher in highest welfare group (Table 4).

\section{Family System}

Family system is an indicator of the social capital of the household and reflects the connectedness within the household and also provides more human, land and other livelihood assets and allows for more collective action and labor force. The incidence of joint family system was dominant in highest welfare quartile and it gradually decreases as we move towards lowest welfare quartile (Table 5).

\section{Education Level of the Family}

The education level of the family members plays an important role in welfare and development of an individual as a component and the society as a whole. Significant results were found for 10 years and above years of schooling for both male and female members of the family among the four quartiles (Table 6). The results become clearer when looking the percent of the family members of each quartile with education level as given in Table 8.

Direct relationship was found between the welfare and education level of the family members as the households with higher level of education and less illiteracy were placed in the upper welfare quartiles. This situation is worse in case of the female education where 70 and $84 \%$ females were illiterate in lower quartiles as compared to 61 and $46 \%$ in the upper two quartiles.

\section{Household Employment}

Significant differences were found in the welfare quartiles for on-farm, off-farm labour force for both male and female. The lowest quartiles were having less labour working at farm and off farm. The household labour force employment status is elaborated in Table 7.

\section{Type of Jobs of Off Farm Workers}

Off farm employment was the main source of income for the households in upper welfare quartiles and its share increases as we move from lower to the upper quartile. Overall governments departments and army came out to be the largest employer for rainfed areas. Nearly half of the labor force was employed in public sector with $24 \%$ 
Working in army and 23\% employed in all other government departments. Labor work was the second main income source as $36 \%$ were working as laborer. Small scale business particularly retail shop was the third off farm income generating activity of the people in rainfed areas. There were clear differences within the welfare quartiles for different off farm activities. The labor force in the lower quartiles was mainly working as daily wage laborers and less in permanent government jobs (Table 8).

\section{Farm Categories}

Farm size of the household plays an important role in the choice of any livelihood strategy in the rural areas. Farm size is one of the major determinants of financial status of a farmer, which in turn affect fanners' ability to adopt modern production practices of farming. Operational land holdings play an important role in the family labor employment as well as income. Production per unit area depends on size of the farm (Iqbal. 1989). The main problem of the barani tract was that mostly there were small sized and fragmented land holdings that might reduce the total production of crops from these very fertile lands (Iqbal, 1989). As we move from lower to relatively more well off quartile the percentage of households in lower farm size category decreases (Table 9).

\section{Composition of Operational Land Holding}

Highly significant differences were observed in land resources of the households among all the welfare groups for all types of land holdings. The farmers in the lower two quartiles have also rented in some land therefore their operational landholding was little higher than the own cultivated land holding and for upper two quartiles it was vice versa. The land ownership plays an important role jn the livelihood and the income of the farming community in the rural areas of the rainfed Pothwar where off farm employment opportunities are very limited. So to increase the living standard of the rural poor calls for enhance productivity of the farm resources. The research and development interventions should target these small poorest of the poor farmers (Table 10).

\section{Cropping Intensity}

Cropping intensity is defined as the ratio between the area under crops and the area operated by the farmers and is reported in percentage terms (Iqbal, 1989). A higher cropping intensity indicated multiple cropping which could help in raising total revenue per cultivated area. Although the results were not statistically significant for cropping intensity both at irrigated and rain fed area yet the farmers in lower welfare quartiles were using their irrigated lands more intensively due to their small landholdings (Table 11).

\section{Income of Household from Different Sources}

Household income from all the sources was calculated and summarized in Table 18. Income was classified into two groups a) off farm income and b) farm income. Significant differences were observed in income form off farm activities and farm sector. The income from all sources increases as we move from lower to upper quartile. In the lower three quartiles females were not employed in the off farm activities and there was no income from remittances and hiring out of tractor as no household in the lower two quartiles own tractor. Income from crops was also higher in upper quartiles due to more cultivated area. Unequal distribution of resources was found in the study area, as income of the lower quartile (Rs. 37332/year) was 4 times less than the income of the highest quartile (Rs. 152732/year).

Similarly highly significant results were found when comparing the per capita income but the intensity was relatively less as the differences reduced to nearly two times against four times in case of overall household income per year. The income of the household was very low as on overall basis all the household lies below the international poverty line of IS per capita per day.

\section{Rural Household Typologies and Poverty Level}

The rural households are poor. About $50 \%$ of 150 sample farmers surveyed fall below the national poverty line of $748.56 \mathrm{Rs} / \mathrm{head} / \mathrm{month}$. This is much higher than the national average poverty level in the rural area. Table 13 given below depicts the percent of households below the national poverty line in each of the welfare quartile. In the lowest quartile two third of the households were below the poverty line as compared to upper quartile in which $37 \%$ households were below poverty line. The level of absolute poverty varies in different ecologies as we can see that in Kaslian most of the households were characterized as poor in all the four quartiles where as at the other two sites nearly half of the households were ranked as poor. At all the three selected site and overall basis the number of households below poverty line decreases as we move from lower to the upper quartile.

\section{Livelihood Typologies}

Livelihood strategies are diverse (Ellis 1998), influenced by linkages in and outside agriculture (Bebbington. 1999; de Haan 2000; Reardon et al 1992), and life cycle family characteristics such as age, education, and the number of family members (Kusterer, 1989; Valdivia, 2000). The degree of diversification of the household portfolio is determined by these characteristics, and by the household's and individual's objectives, such as risk management practices, and/or strategies available to cope with shocks. In areas of greater risk household strategies are expected to be more diversified as a mean to minimize possible shocks from negative climate events, especially when loss-management strategies are limited (Dunn et al 1996).

As Hans et al (2003) have concluded that livelihood strategies can be a useful and quantifiable concept especially when exploring land and soil conservation measures. Conservation practices and investments need to 
be appropriate for the production system, agro-ecological conditions, and the livelihood strategy, the livelihood strategy framework has the potential to be an important tool in both the formulation and targeting of policy.

Water, land, livestock, crops and knowledge are essential resources/assets in generating the income for families in rural areas of the world. Although agriculture may not be the sole source of their income, it is a major component in the Tropics. Access, control, and management of these resources contribute to shape which activities are pursued, which goods produced, and me ability to retain the benefits of their labor. Access and control of resources and capitals, through diverse cultural, political, economic, ecological and agricultural settings, the nature of the relation between access and control of diverse assets allow individuals to negotiate their livelihood strategies and improve well being in rural areas (Valdivia and Gilles 1996). When access is limited or opportunistic due to lack of institutions supporting this access by individuals, the ability to sustain the natural resource base and other human assets is endangered.

Overall, rural households depend on the income from off-farm employment (57\%). followed by crop production and livestock $(12 \%)$. The highest welfare quartiles were those relatively more dependent on off-farm employment, less on crops and have the least income from livestock. The lowest quartiles in poverty index are those more dependent on income from crop production, following by off-farm income and livestock production. However, the lowest quartiles are relatively more dependent on livestock as compared with those in the highest quartiles (Table 14).

Keeping in view the above discussion on the availability of all resources and income of the household from different activities the households could be grouped into three clusters with similar livelihood typologies.

\section{Group 1}

Mixed crop livestock farming: Crop production as the main activity along with livestock farming but the share of income form off farm activities is ranked at second number. The households in the lowest quartile mainly follow this typology. However, the lowest quartile is relatively more dependent on livestock as compared with those in the highest quartiles.

\section{Group II}

Agriculture and off farm employment: Households derive half of the income from crops and livestock and half from off farm employments. The dependence on crop is less than the first category and more on livestock still the income from crops was almost 50\% higher than die income from livestock.

\section{Group III}

Highest welfare quartiles were those relatively more dependent on off-farm employment, less on crops and have the least income from livestock. The share of livestock income is only 6\%. Most of the family members are engaged in off farm activities and also remittances from the major share of income. Agriculture is considered a part time activity and fewer resources are diverted from off-farm to increase the farm productivity and income.

\section{CONCLUSION AND RECOMMENDATIONS}

The ways people make a living, and the constraints and opportunities they face in doing so can strongly affect the status and management of common-pool resources. Livelihood strategies in the rain fed areas are dynamic particularly due to uncertainty in agriculture due to erratic rainfall. Therefore people are engaged in different livelihood activities and always looking for ample income sources. Crop improvement research faces more challenges in the dry areas and the adoption of soil and water conservation practices for sustainable livelihood with long-term environmental and economic benefits is uncertain. Farmers in the dry areas face both environmental and socio economic hurdles that make the incidence of poverty relatively high. Under these conditions NARC should accept the challenge to develop and provide technological packages that could bring tangible improvements in the livelihood of rural poor in the rain fed areas with mix crop and livestock farming system.

The present study employs the livelihood strategy conceptual framework to analyze data collected on 150 rural households from the three Integrated Research Sites of BVDP. Households were grouped into four welfare quartiles to identify different livelihood strategies using Principle Component Analysis based on the household assets. Three main livelihood strategies were identified through analyzing the resource availability and income in different welfare quartiles of the sample households. The livelihood strategies identified include: a) Mixed crop livestock farming with more dependence on crop production; b) Agriculture and off farm employment with half of the income from crops and livestock and half from off farm employments; c) The highest welfare quartile were those relatively more dependent on off-farm employment, less on crops and had the least income from livestock.

The main conclusions drawn from the present study on livelihood typologies of Pothwar district are following:

- Improvement in the crop livestock system through development of drought tolerant food and fodder crops. Productivity enhancement of livestock through improved breeds and improved flock management. 
- Improved production of cash crops such as groundnut and pulses along with the promotion of high value crops at the scarce irrigation water wherever available in rain fed areas.

- Adoption of improved soil and water conservation practices for sustainable use of available resources.

- Development of local institutions, rural networks, enterprises, and farmer-interest groups are essential to out-scale the diffusion of these promising technologies. More active participation of farmers in technology generation and evaluation is essential for rapid technology adoption.

- An integrated approach with strong coordination between research and development is required to make any sizeable impact on income to cover several production activities;

- Market development for farm output is critical to improve cash income. This would motivate the households with more off farm income (upper quartile) to divert the resources of off farm to agriculture generating more employment and income for the rural landless. Development of micro enterprises such as sheep/goat fattening are linked with farm production.

- Development of small-scale irrigation facilities such as dug wells and mini dams for food and fodder security in the critical periods. Micro credit for crop livestock and micro enterprise development.

\section{REFERENCES}

Bebbington, A. 1999. Capitals and Capabilities: A Framework for Analyzing Peasant Viability, Rural Livelihoods and Poverty. World Development. 27(12):2021-2044.

Carney, D. 1998. Sustainable rural livelihoods: What contribution can we make? Natural Resource Advisers Conference. July 1998. DFID, London, UK.

Chambers, R. and G. Conway 1992. Sustainable rural livelihoods: Practical concepts for the 21 st century. IDS Discussion Paper 296. Brighton: IDS.

de Haan, L. J. 2000. Globalization, Localization and Sustainable Livelihood. Sociologia Ruralis. 40(3): 339365.

DFID 2001. Sustainable livelihoods guidance sheets. Department for International development. London, livelihoods@dfid.gov.uk

Dunn. F., Kalaitzandonakes N., and Valdivia, C. 1996. Risk and the impacts of micro-enterprise services. Assessing the Impacts of Microenterprise Services (AIMS). MSI. Washington DC.

Ellis, F. 1993. Peasant Economics: Farm households and agrarian development. Second Edition. Cambridge University Press. 38

Ellis, F. 1998. Household Strategies and Rural Livelihood Diversification. The Journal of Development Studies. 35(1): 1-38.

Ferguson, A. E. 1992. Differences among women farmers: Implications for African agricultural research programs. Proceedings A workshop on Social Science Research and the CRSP's June 9-11, 1992. Lexington Kentucky. INTSORMIL Publication No. 93-3. Pp.47-62.

Hans G.P. Jansen, Amy Damon, John Pender. Willem Wielemaker and Rob Schipper 2003. Sustainable Development In The Hillsides Of Honduras: A Livelihoods Approach Paper for the international workshop on "Reconciling Rural Poverty Reduction and Resource Conservation: Identifying Relationships and Remedies", Cornell University, May 2-3, 2003.

Kusterer. K. 1989. Small fanner attitudes and aspirations. US AID Program Evaluation Discussion Paper No. 26. USAID, Washington. DC.

Reardon, T., Delgado, C. and Matlon, P. 1992. Determinants and effects of income diversification amongst farm households in Burkina Faso. The Journal of Development Studies. 28 (2) : 264-296.

Valdivia, C. 2001. Gender, livestock assets, resource management, and food security: Lessons from the SRCRSP. Agriculture and Human Values. 18: 27-39.

Valdivia. C. and J. L. Gilles. 2001. Gender and resource management: Households and groups. strategies and transitions. Agriculture and Human Values. 18(1): 5-9.

Table 1. Distribution of Households by Welfare Groups at the Three Locations

\begin{tabular}{|l|c|c|c|c|c|}
\hline \multirow{2}{*}{ Site } & \multicolumn{4}{|c|}{ Welfare Group } & \multirow{2}{*}{ Overall } \\
\cline { 2 - 5 } & Lowest 25\% & $\mathbf{2 5 \%}-\mathbf{5 0} \%$ & $\mathbf{5 0 \% - 7 5 \%}$ & Highest 25\% & \\
\hline Rawalpindi & $10(31)$ & $10(31)$ & $9(28)$ & $3(9)$ & $32(100)$ \\
\hline Chakwal & $16(34)$ & $9(19)$ & $8(17)$ & $14(30)$ & $47(100)$ \\
\hline Attock & $12(17)$ & $117(24)$ & $22(31)$ & $20(28)$ & $71(100)$ \\
\hline Overall & $38(25)$ & $36(24)$ & $39(26)$ & $37(25)$ & $150(100)$ \\
\hline
\end{tabular}

(The figures given in the parenthesis are the percentages) 
Table 2: Characteristics of Household Heads by Welfare Groups

\begin{tabular}{|l|c|c|c|c|c|c|}
\hline \multicolumn{1}{|c|}{ Characteristics } & $\begin{array}{c}\text { Lowest } \\
\mathbf{2 5 \%}\end{array}$ & $\begin{array}{c}\mathbf{2 5 -} \\
\mathbf{5 0 \%}\end{array}$ & $\begin{array}{c}\mathbf{5 0}- \\
\mathbf{7 5 \%}\end{array}$ & $\begin{array}{c}\text { Highest } \\
\mathbf{2 5 \%}\end{array}$ & $\begin{array}{c}\text { Over } \\
\text { all }\end{array}$ & Sig. \\
\hline Ave. age years & 52.1 & 48.4 & 56.7 & 56.2 & 53.4 & 0.046 \\
\hline Formal education (years) & 5.4 & 4.7 & 5.9 & 7.3 & 5.8 & 0.057 \\
\hline Farming experience years & 229 & 20.8 & 21.9 & 18.3 & 21.0 & 0.569 \\
\hline $\begin{array}{l}\text { Previous off farm job experience } \\
\text { years }\end{array}$ & 4.3 & 3.6 & 4.1 & 3.6 & 3.9 & 0.982 \\
\hline $\begin{array}{l}\text { Previous off farm job experience } \\
\text { years }\end{array}$ & 8.4 & 6.9 & 13.8 & 17.6 & 11.7 & 0.000 \\
\hline
\end{tabular}

Table 3: Type of Present off Farm Work of Household Heads

\begin{tabular}{|l|c|c|c|c|c|}
\hline \multicolumn{1}{|c|}{ Work Type } & Lowest 25\% & $\mathbf{2 5 - 5 0 \%}$ & $\mathbf{5 0 - 7 5 \%}$ & Highest 25\% & Overall \\
\hline Labor & 44 & 40 & 33 & 30 & 37 \\
\hline Govt, servant & 11 & 50 & 22 & 20 & 26 \\
\hline Business & 44 & 10 & 44 & 50 & 37 \\
\hline
\end{tabular}

Significance level of Chi-Square test- 0.405

Table 4: Type of Previous Off Farm Work of Household Heads

\begin{tabular}{|l|c|c|c|c|c|}
\hline \multicolumn{1}{|c|}{ Work Type } & Lowest 25\% & $\mathbf{2 5 - 5 0 \%}$ & $\mathbf{5 0 - 7 5 \%}$ & Highest 25\% & Overall \\
\hline Labor & 35 & 19 & 26 & 4 & 20 \\
\hline Govt, servant & 55 & 75 & 74 & 85 & 73 \\
\hline Business & 5 & 6 & 0 & 0 & 2 \\
\hline Abroad & 5 & 0 & 0 & 11 & 4 \\
\hline
\end{tabular}

Significance level of Chi-Square iest $=0.079$

Table 5: Family Living System across Welfare Quartiles

\begin{tabular}{|l|c|c|c|c|c|}
\hline \multicolumn{1}{|c|}{ Family Type } & Lowest 25\% & $\mathbf{2 5 - 5 0 \%}$ & $\mathbf{5 0 - 7 5 \%}$ & Highest 25\% & Overall \\
\hline Joint family & 24 & 47 & 64 & 84 & 55 \\
\hline Single family & 76 & 53 & 36 & 16 & 45 \\
\hline
\end{tabular}

Significance level of Chi-Square test -0.0000

Table 6: Distribution of Family Members by Education Level

\begin{tabular}{|c|c|c|c|c|c|c|}
\hline \multirow{2}{*}{ Male Education } & Lowest 25\% & $25-50 \%$ & $50.75 \%$ & Highest 25\% & Overall & \multirow{2}{*}{ Sig. } \\
\hline & \multicolumn{5}{|c|}{ Mean Value } & \\
\hline Illiterate & 0.34 & 0.75 & 0.49 & 0.51 & 0.52 & 0.17 \\
\hline Primary & 0.37 & 0.47 & 0.46 & 0.41 & 0.43 & 0.93 \\
\hline Middle & 0.45 & 0.81 & 0.95 & 1.08 & 0.82 & 0.19 \\
\hline Matric & 0.42 & 0.47 & 0.67 & 1.11 & 0.67 & .0029 \\
\hline FA & $0 . \mathrm{C} 3$ & 0.08 & 0.21 & 0.41 & 0.18 & 0.003 \\
\hline Graduate & 0.08 & 0.06 & 0.10 & 0.38 & 0.15 & 0.032 \\
\hline \multirow[t]{2}{*}{ Technical educated } & 0.00 & 0.00 & 0.0 & 0.00 & 0.00 & - \\
\hline & \multicolumn{6}{|c|}{ Female Education } \\
\hline Illiterate & 1.37 & 1.92 & 1.77 & 1.70 & 1.69 & 0.300 \\
\hline Primary & 0.29 & CI- & 0.51 & 0.86 & 0.45 & 0.001 \\
\hline Middle & 0.21 & 0.14 & 0.26 & 0.43 & 0.26 & 0.154 \\
\hline Matric & 0.05 & 0.08 & 0.26 & 0.32 & 0.18 & 0.027 \\
\hline FA & 0.00 & 0.00 & 0.08 & 0.14 & 0.05 & 0.054 \\
\hline Graduate & 0.03 & 0.00 & 0.03 & 0.22 & 0.07 & 0.011 \\
\hline Technical educated & 0.00 & 0.00 & 0.0 & 0.00 & 0.00 & - \\
\hline
\end{tabular}


Table 7. Household Labour Allocation by Welfare Quartiles

\begin{tabular}{|l|c|c|c|c|c|c|c|}
\hline \multicolumn{1}{|c|}{ Male } & $\begin{array}{c}\text { Lowest } \\
\mathbf{2 5 \%}\end{array}$ & $\begin{array}{c}\mathbf{2 5 -} \\
\mathbf{5 0 \%}\end{array}$ & $\mathbf{5 0 . 7 5 \%}$ & \multicolumn{2}{c|}{$\begin{array}{c}\text { Highest } \\
\mathbf{2 5 \%}\end{array}$} & Overall & Sig. \\
\hline \multicolumn{7}{|c|}{ Average \# } \\
\hline On-Farm Full Time & 0.8 & 1.0 & 1.1 & 1.5 & 1.1 & 0.008 \\
\hline On-Farm Part Time & 0.5 & 0.8 & 0.9 & 1.1 & 0.8 & 0.053 \\
\hline Off farm & 0.3 & 1.0 & 1.1 & 1.8 & 1.1 & 0.000 \\
\hline \multicolumn{7}{|c|}{ Female } \\
\hline On-Farm Full Time & 0.8 & 0.6 & 0.4 & 0.4 & 0.5 & 0.29 \\
\hline On-Farm Part Time & 0.4 & 0.9 & 1.2 & 2.5 & 1.3 & 0.000 \\
\hline Off farm & 0.0 & 0.0 & 0.0 & 0.1 & 0.0 & 0.093 \\
\hline $\begin{array}{l}\text { HH with Female involvement in } \\
\text { farming (\%) }\end{array}$ & 76 & 78 & 77 & 95 & 81 & $\begin{array}{c}\text { Sq- } \\
\text { Sq }\end{array}$ \\
\hline
\end{tabular}

Table 8: Type of Jobs of Off-Farm Workers by Welfare Quartiles

\begin{tabular}{|l|c|c|c|c|c|}
\hline \multicolumn{1}{|c|}{ Job Type } & Lowest 25\% & $\mathbf{2 5 - 5 0 \%}$ & $\mathbf{5 0 - 7 5 \%}$ & Highest 25\% & Overall \\
\hline Army & 17 & 31 & 24 & 21 & 24 \\
\hline Govt, service & 17 & 12 & 24 & 38 & 23 \\
\hline Labour & 42 & 50 & 38 & 17 & 36 \\
\hline Business & 25 & 8 & 14 & 25 & 16 \\
\hline
\end{tabular}

Significance level of Chi Square test $=0.23$

Table 9: Farm Size Categories by Welfare Quartiles

\begin{tabular}{|l|c|c|c|c|c|}
\hline \multicolumn{1}{|c|}{ Farm Size } & Lowest 25\% & $\mathbf{2 5 - 5 0 \%}$ & $\mathbf{5 0 - 7 5 \%}$ & Highest 25\% & Overall \\
\hline Up to 1.50 hectares & 68 & 56 & 28 & 22 & 43 \\
\hline 1.5.1 to 3.00 hectares & 26 & 39 & 41 & 30 & 34 \\
\hline Greater than 3.00 hectares & 5 & 6 & 31 & 49 & 23 \\
\hline
\end{tabular}

Significance level of Chi-Square test $=0.000$

Table 10 Composition of Operational Landholding by Welfare Quartiles (Hectares)

\begin{tabular}{|l|c|c|c|c|c|c|}
\hline \multicolumn{1}{|c|}{ Type of Land } & Lowest 25\% & $\mathbf{2 5 - 5 0 \%}$ & $\mathbf{5 0 . 7 5 \%}$ & Highest 25\% & Overall & Sig. \\
\hline Total own land & 1.6 & 1.8 & 3.9 & 7.8 & 32.8 & 0.00 \\
\hline Cultivated & 1.2 & 1.3 & 2.5 & 4.0 & 2.3 & 0.00 \\
\hline Non cultivated & 0.4 & 0.5 & 1.4 & 3.8 & 1.5 & 0.00 \\
\hline Operational land & 1.4 & 1.5 & 2.4 & 3.8 & 2.3 & 0.00 \\
\hline Irrigated & 0.5 & 0.9 & 1.3 & 1.4 & 1.0 & 0.00 \\
\hline Un-irrigated & 0.9 & 0.6 & 1.1 & 2.5 & 1.3 & 0.00 \\
\hline
\end{tabular}

Table 11 Cropping Intensity at Farms by Welfare Quartile

\begin{tabular}{|l|c|c|c|c|c|}
\hline \multicolumn{1}{|c|}{ Cropping Intensity } & Lowest 25\% & $\mathbf{2 5 - 5 0 \%}$ & $\mathbf{5 0 . 7 5 \%}$ & Highest 25\% & Sig. \\
\hline Irrigated area & 147 & 138 & 129 & 125 & 0.299 \\
\hline Rainfed area & 123 & 112 & 114 & 125 & 0.470 \\
\hline
\end{tabular}


Table 12. Income of Household by Welfare Quartiles

\begin{tabular}{|l|c|c|c|c|c|c|}
\hline \multicolumn{1}{|c|}{ Income Source } & Lowest 25\% & $\mathbf{2 5 - 5 0 \%}$ & $\mathbf{5 0 . 7 5 \%}$ & Highest 25\% & Overall & \multirow{2}{*}{ Sig. } \\
\hline Off Farm & \multicolumn{7}{|c|}{ Rupees } \\
\hline Adult male & 9135 & 21167 & 30166 & 71222 & 32805 & 0.000 \\
\hline Adult female & 0 & 0 & 0 & 2173 & 536 & 0.176 \\
\hline Pension & 2653 & 2693 & 7918 & 8748 & 5535 & 0.000 \\
\hline Remittances & 0 & 0 & 923 & 15703 & 413 & 0.004 \\
\hline Hiring out tractor & 0 & 0 & 2026 & 5189 & 1807 & 0.011 \\
\hline \multicolumn{7}{|c|}{ Farm Income } \\
\hline Khaarif crops & 4640 & 4905 & 6155 & 10024 & 6185 & 0.018 \\
\hline Rabi crops & 14455 & 11728 & 16806 & 31097 & 18517 & 0.000 \\
\hline Livestock & 6451 & 10575 & 11366 & 8577 & 9243 & 0.093 \\
\hline Total Income Rs./Year & 37332 & 50068 & 75360 & 152732 & 78741 & 0.000 \\
\hline Per capita income (Rs/year) & 8289 & 9074 & 9908 & 15117 & 10582 & 0.003 \\
\hline Per capita income (\$/ycar) & 142.91 & 156.45 & 170.82 & 260.64 & 182.46 & 0.003 \\
\hline $\begin{array}{l}\text { Per capita income } \\
\text { (Rs/month) }\end{array}$ & 691 & 756 & 826 & 1260 & 882 & 0.003 \\
\hline Per capita income (S/day) & 0.39 & 0.43 & 0.47 & 0.71 & 0.50 & 0.003 \\
\hline
\end{tabular}

Table 13. Poverty at Site (H less than Rs. 748/month/capita [\%])

\begin{tabular}{|l|c|c|c|c|c|c|}
\hline & Lowest 25\% & $\mathbf{2 5 - 5 0 \%}$ & $\mathbf{5 0 . 7 5 \%}$ & Highest 25\% & Total & Chi-sq. \\
\hline Hafizabad & 70 & 40 & 44 & 33 & 50 & 0.485 \\
\hline Jarmot & 50 & 89 & 50 & 14 & 47 & 0.006 \\
\hline Kaslian & 83 & 65 & 55 & 55 & 62 & 0.347 \\
\hline Overall & 66 & 64 & 51 & 37 & 55 & 0.057 \\
\hline
\end{tabular}

Table 14. Income from Different Sources

\begin{tabular}{|c|c|c|c|c|c|}
\hline \multirow{2}{*}{ Income Sources } & Lowest $25 \%$ & $25-50 \%$ & $50-75 \%$ & Highest 25\% & \multirow{2}{*}{ Overall } \\
\hline & \multicolumn{4}{|c|}{ Percent Share } & \\
\hline Income from crops & 51 & 31 & 30 & 27 & 31 \\
\hline Income from Livestock & 17 & 21 & 15 & 5 & 12 \\
\hline Income from Off Farm Activities & 32 & 48 & 54 & 67 & 57 \\
\hline
\end{tabular}

